\title{
KETERANGAN MODALITAS DALAM BERITA "ALEXIS YANG TERUS EXIS" PADA MAJALAH TEMPO EDISI 29 JANUARI-4 FEBRUARI 2018
}

\author{
Ari Musdolifah \\ Universitas Balikpapan \\ Pos-el: ary.musdolifah@uniba-bpn.ac.id
}

\begin{abstract}
ABSTRAK
Penelitian tentang Keterangan Modalitas dalam Berita "Alexis yang Terus Exis" Pada Majalah Tempo Edisi 29 Januari-4 Februari 2018 dilatarbelakangi oleh pemikiran bahwa penggunaan bahasa dalam media cetak sangat menarik karena terdapat kalimat-kalimat yang menunjukkan modalitas untuk memberikan kesan tertentu kepada pembaca. Adapun tujuan dari penelitian ini adalah menjelaskan wujud keterangan modalitas dalam berita "Alexis yang Terus Exis" pada Majalah tempo edisi 29 Januari-4 Februari 2018. Pendekatan yang digunakan dalam penelitian ini adalah kualitatif. Adapun metode yang digunakan adalah deksriptif. Sementara itu, sumber datanya adalah berita "Alexis yang Terus Exis" dalam Majalah Tempo edisi 29 Januari-4 Februari 2018. Wujud data adalah kalimat yang mengandung kata modalitas. Berdasarkan hasil penelitian dapat ditemukan wujud katerangan modalitas intensional, epistemis, dinamik, dan deontik. Unsur kata yang ditemukan adalah ingin, antusias, berjanji, seharusnya, meyakini, membenarkan, menurut, sepertinya, kemungkinan, bisa, dan izin. Selain itu, perspektif penulis berita Majalah Tempo dalam menanggapi wujud keterangan modalitas tersebut adalah perspektif positif dan negatif.
\end{abstract}

Kata Kunci : modalitas, media cetak, kalimat.

\begin{abstract}
Research on Modality Description in News "Existing Alexis Exist" In Tempo Magazine January 29-February 4, 2018 edition is motivated by the idea that the use of language in print media is very interesting because there are sentences that show the modalities to give a particular impression to the reader. The purpose of this study is to explain the form of information in the news story "Existing Alexis Exist" in the magazine tempo 29 January-4 February 2018 edition. The approach used in this study is qualitative. The method used is descriptive. Meanwhile, the data source is the news "Existing Alexis Exist" in Tempo Magazine January 29-February 4, 2018 edition. Data form is a sentence that contains the word modalities. Based on the results of the research can be found the form of information intentional, modalities, epistemic, dynamic, and deontic. The element of the word found is to want, enthusiastically, to promise, should, believe, justify, according to, seem, possibilities, possibilities, and permission. In addition, the perspective of news writer Tempo Magazine in response to the form of description of the modalities is a positive and negative perspective.
\end{abstract}

Keywords : modalities, printed media, sentence.

Vol. 1, No. 1. Juni 2018 


\section{PENDAHULUAN}

Bahasa asdalah alat untuk menyampaikan pikiran dan perasaan kepada orang lain (Lubis, 1991). Hal tersebut dikatakan karena tanpa bahasa, manusia akan sulit untuk memahami perkataan orang lain. Achmad \& Abdullah (2002) menyatakan bahwa bahasa adalah sistem lambang bunyi yang bersifat arbitrer yang dipergunakan oleh para anggota kelompok sosial untuk bekerja sama. Penguasaan terhadap bahasa merupakan pelengkap bagi manusia untuk membedakan manusia dengan makhluk hidup yang lainnya. Bahasa sangat diperlukan dalam berbagai bidang kehidupan karena untuk dapat mengetahui segala sesuatu yang dihayati, dipahami, dialami, dirasakan, dan dipikirkan oleh orang lain dapat diketahui dengan bahasa, baik lisan maupun tulisan.

Wacana adalah rentetan kalimat yang berkaitan, yang menghubungkan proposisi yang satu dengan proposisi lainnya di dalam kesatuan makna (Moeliono dalam Junaiyah \& Arifin, 2010). Wacana merupakan satuan bahasa yang terlengkap, yang menempati urutan teratas dalam kebahasaan dan merupakan satuan gramatikal tertinggi dan terbesar. Dalam kesatuan makna, wacana adalah satu kesatuan yang utuh karena bagian satu dengan bagian yang lainnya saling berkaitan. Oleh sebab itu, wacana adalah satuan bahasa yang paling lengkap karena lebih dari klausa dan kalimat yang memiliki kohesi dan koherensi, awal dan akhir yang jelas, berkesinambungan, baik dalam bentuk lisan maupun tulisan.

Salah satu bentuk penyajian wacana oleh media massa adalah berita, baik itu berita tulis dalam surat kabar, majalah, tabloid, maupun berita yang disampaikan secara lisan melalui siaran radio dan televisi. Berita adalah segala laporan mengenai peristiwa, kejadian, gagasan, fakta yang menarik perhatian dan penting untuk disampaikan atau dimuat dalam media massa agar diketahui atau menjadi kesadaran umum (Barus, 2010). Oleh sebab itu, berita memuat unsur-unsur penting, yaitu peristiwa, kejadian, gagasan, fakta, menarik perhatian, penting, dan dilaporkan dalam media massa. Berita harus dilaporkan ke dalam media massa agar diketahui masyarakat umum jika tidak maka hal tersebut bukanlah berita. Artinya, fakta menjadi berita bila dilaporkan.

Berita-berita yang dimuat di berbagai media massa mengandung informasi yang sangat kaya. Hal tersebut karena berita merupakan sumber informasi dunia yang memuat segala peristiwa pada masyarakat dalam melaksanakan kehidupan bersama. Melalui berita, masyarakat akan memperoleh informasi yang dapat menambah wawasan dan pengetahuan, yang nantinya akan bermanfaat bagi masyarakat itu sendiri. Berdasarkan hal tersebut, media massa dituntut untuk memberikan informasi aktual yang dapat dipertanggung jawabkan dengan didukung oleh format, kemasan, dan sajian berita yang baik.

Berita dapat ditemukan di media cetak dan media elektronik. Berdasarkan persoalannya, salah satu jenis berita yang berkaitan dengan pemerintahan adalah berita politik. Berita politik disajikan kepada masyarakat dalam bentuk siaran, internet, cetak, atau dari mulut ke mulut kepada orang ketiga atau orang banyak. Politik adalah kegiatan yang secara kolektif mengatur perbuatan manusia dalam suatu kondisi konflik sosial (Nimmo dalam Zen, 2004). Politik berawal dari sebuah perbedaan antara 
manusia satu dengan manusia yang lainnya yang merangsang terjadinya konflik. Salah satu media yang didalamnya terdapat berita politik adalah Majalah Tempo. Jenis bahasa yang digunakan dalam majalah ini adalah bahasa tulis.

Bahasa tulis memuat kata, frase, klausa, kalimat dalam sebuah paragraf yang menjadi satu kesatuan yang utuh dalam bentuk wacana.. Di dalam wacana tersebut, terdapat paragraf yang menjadi satu kesatuan utuh yang saling berkaitan. Paragraf sendiri merupakan gabungan dari beberapa kalimat yang memuat kalimat utama dan kalimat penjelas. Kalimat-kalimat tersebut merupakan unsur yang paling besar dibandingkan dengan frase dan klausa. Kalimat adalah ucapan bahasa yang memiliki arti penuh dan batas keseluruhannya dan batas keseluruhannya ditentukan oleh turunnya suara. Sebuah kalimat yang lengkap harus memiliki subjek, predikat, objek, dan keterangan. Keterangan dibagi lagi menjadi dua jenis, yaitu keterangan berdasarkan maknanya dan keterangan berdasarkan fungsinya. Penelitian ini difokuskan pada keterangan berdasarkan makna, yaitu pada keterangan modalitas.

Modalitas adalah bagian kluasa yang menyatakan kemungkinan, harapan, kepastian, kesangsian, dan kebalikan dari itu (Kridalaksana dalam Markhamah, 2009). Perwujudan modalitas dalam suatu bahasa terkait dengan struktur bahasa itu sendiri dan ada kalanya berbeda dengan bahasa yang lain. Modalitas dibagi menjadi empat, yaitu modalitas intensional, epistemik, deontik, dan dinamik (Alwi, 1990). Modalitas tersebut memiliki makna dan pengungkap sesuai dengan kalimatnya masing-masing. Dalam bahasa, unsur-unsur yang digunakan dalam pembicara untuk mengungkapkan sikapnya tergolong dalam kategori leksikal. Unsur-unsur tersebut dapat berupa kata, frase, atau klausa. Modalitas digunakan untuk menyampaikan maksud pembicara yang bervariasi dalam komunikasi. Keragaman tersebut menunjukkan nuansa sikap yang bervariasi dan bergradasi. Bervariasi di sini adalah macam-macam makna yang diinginkan dengan sikap pembicara, sedangkan bergradasi adalah sikap yang bersifat santun atau tidak.

Berita "Alexis yang Terus Exis" merupakan salah satu berita yang terdapat dalam Majalah Tempo edisi 29 Januari-4 Februari 2018. Berita tersebut memuat beberapa keterangan modalitas yang mendukung isi pemberitaan tersebut. Salah satu bentuk keterangan modalitas yang terdapat dalam majalah tersebut terdapat pada kalimat, "Sejak awal, pengunjung bisa memilih Lady Companion (LC) yang berderet di ruangan tertutup gorden tipis di belakang resepsionis lantai tiga". Keterangan modalitas dalam kalimat tersebut ditandai dengan kata bisa. Keterangan modalitas tersebut adalah jenis keterangan modalitas epistemik yang terkait dengan kemungkinan. Berdasarkan kalimat tersebut, maka makna yang muncul adalah terdapatnya kemungkinan dari sebuah peristiwa yang dialami oleh pengunjung tersebut.

Makna dalam kalimat dapat dianalisis melalui konteksnya. Badara (2012) menyatakan bahwa konteks memasukkan semua situasi dan hal yang berada di luar teks dan mempengaruhi pemakaian bahasa, seperti partisipan dalam bahasa, situasi di mana teks tersebut diproduksi, fungsi yang dimaksudkan, dan sebagainya. Upaya mengetahui makna dalam sebuah kalimat dapat dilakukan dengan menganalisis keterangan modalitas dalam sebuah kalimat. Dengan demikian, akan 
diketahui makna apa yang terkandung di dalam tulisan tersebut.

Peneliti tertarik menganalisis keterangan modalitas dalam berita "Alexis yang Terus Exis" pada Majalah Tempo edisi 29 Januari-4 Februari 2018 karena objek dalam penelitian ini belum pernah ada yang meneliti sehingga hasilnya dapat melengkapi penelitian sebelumnya. Selain itu, analisis yang dilakukan pada kalimat-kalimat dalam berita tersebut dapat menambah pemahaman tentang kalimat khususnya dan wacana pada umumnya. Berdasarkan pemikiran tersebut, muncul persoalan yang patut untuk dikaji dengan menjawab "Bagaimana bentuk-bentuk modalitas dalam berita "Alexis yang Terus Exis" pada Majalah Tempo edisi 29 Januari-4 Februari 2018?”.

\section{Keterangan Modalitas}

Berita "Alexis yang Terus Exis" dalam Majalah Tempo edisi 29 Januari-4 Februari 2018 dianalisis dengan menggunakan teori keterangan modalitas menurut Alwi (1990) yang meliputi, modalitas intensional, epistemik, deontik, dan dinamik. Modalitas intensional terdiri dari kadar keinginan, kadar kemauan, kadar maksud, kadar keakanan; harapan, ajakan, pembiaran, dan pemintaan. Modalitas epistemik meliputi, kemungkinan, keteramalan, keharusan, dan kepastian. Sementara itu, modalitas deontic meliputi, izin dan perintah. Dan, modalitas dinamik meliputi, kemampuan.

Modalitas dalam sebuah kalimat disebut juga dengan predikat. Dengan adanya modalitas dalam sebuah kalimat, maka makna dalam keseluruhan kalimat akan berubah. Selain itu, dengan adanya modalitas tertentu dalam sebuah kalimat, maka kalimat dapat berubah menjadi sebuah kalimat yang tegas, ragu, lembut, pasti, dan sebagainya (Widjono, 2007).
Sementara itu, modalitas merupakan satu himpunan dalam satu kalimat yang bercirikan negasi, waktu, modus, dan aspek (Parera, 2009). Sementara itu, Chaer (1994) menjelaskan bahwa modalitas adalah keterangan dalam kalimat yang menyatakan sikap pembicara terhadap hal yang dibicarakan, yaitu mengenai perbuatan, keadaan, peristiwa, atau sikap terhadap lawan bicaranya. Sikap tersebut dapat berupa penyataan kemungkinan, keinginan, atau keizinan. Berdasarkan pengertian modalitas tersebut, contoh penerapan modalitas dalam kalimat dapat dijabarkan sebagai berikut.

1. Adik saya kemungkinan besar seorang politikus

2. Ibu ingin menunaikan ibadah haji

3. Kalau tidak hujan, Ayah pasti datang

4. Anda boleh tinggal di sini sampai besok

Media cetak adalah alat komunikasi yang bersifat satu arah (tetapi bukan 100 persen monolog) (Dewabrata, 2004). Hal tersebut dikarenakan tidak adanya waktu untuk melakukan dialog yang spontan atau seketika. Meskipun demikian, tidak menutup kemungkinan bahwa media cetak dapat melakukan komunikasi secara dua arah.

Berita adalah produk dari sebuah usaha/proses menyusun fakta-fakta sosial menjadi sesuatu yang menarik untuk dikonsumsi (Rizki, 2016). Sementara itu, Barus (2010) menyatakan bahwa berita adalah segala laporan mengenai peristiwa, kejadian, gagasan, fakta, yang menarik perhatian dan penting untuk disampaikan atau dimuat dalam media massa agar diketahui atau menjadi kesadaran umum. Berdasarkan hal tersebut, berita adalah sebuah usaha atau proses menyusun laporan fakta-fakta sosial yang menarik 
dan penting untuk disampaikan atau dimuat dalam media massa untuk dikonsumsi masyarakat.

Berdasarkan persoalannya, berita dapat dikelompokkan menjadi, berita politik, ekonomi, sosial, budaya, hukum, olahraga, militer, kriminal atau kejahatan, dan sebagainya. Dalam media cetak, Dalam media cetak, seperti majalah dan surat kabar, berbagai bidang tersebut, ditempatkan pada rubriknya masingmasing. Sementara itu, dalam media online, dibuat dengan nama manajemen konten yang berlapis-lapis jendela atau nagivasi untuk masuk kepada menunya (bidangnya) atau bahkan lokasi beritanya.

\section{METODE PENELITIAN}

Sesuai dengan tujuan dalam penelitian ini, serta teori yang akan digunakan dalam analisis, maka pendekatan yang digunakan adalah pendekatan kualitatif. Dalam penelitian ini, data yang ditemukan dalam berita "Alexis yang Terus Exis" dalam Majalah Tempo edisi 29 Januari-4 Februari 2018 dideskripsikan dalam bentuk kalimat agar dapat interpretasikan untuk mendapat jawaban dari masalah yang telah dirumuskan dengan cara menelaah dan mengalisis data dengan berbagai referensi yang relevan.

Data penelitian ini berupa kalimat yang terdapat pada berita "Alexis yang Terus Exis" dalam Majalah Tempo edisi 29 Januari-4 Februari 2018 yang terkait dengan permasalahan penelitian tentang keterangan modalitas. Sumber data dalam penelitian ini adalah berita "Alexis yang Terus Exis" dalam Majalah Tempo edisi 29 Januari-4 Februari 2018.

Penelitian ini berfokus pada wujud keterangan modalitas pada berita "Alexis yang Terus Exis" dalam Majalah Tempo edisi 29 Januari-4 Februari 2018 untuk menggambarkan perspektif penulis berita dalam Majalah Tempo terhadap modalitas wujud keterangan modalitas tersebut.

\section{HASIL DAN PEMBAHASAN}

Hasil penelitian yang akan dijelaskan pada penelitian ini adalah wujud keterangan modalitas dalam berita "Alexis yang Terus Exis" dalam Majalah Tempo edisi 29 Januari-4 Februari 2018. Keterangan modalitas dalam berita tersebut terdiri dari, modalitas intensional, epistemik, deontik, dan dinamik. Modalitas intensional terdiri dari kadar keinginan, kadar kemauan, kadar maksud, kadar keakanan; harapan, ajakan, pembiaran, dan pemintaan. Modalitas epistemik meliputi, kemungkinan, keteramalan, keharusan, dan kepastian. Sementara itu, modalitas deontik meliputi, izin dan perintah. Dan, modalitas dinamik meliputi, kemampuan.

Wujud keterangan modalitas tersebut diklasifikasikan berdasarkan penomoran data sebagai berikut.

$\begin{array}{ll}\text { MT } & \text { : Majalah Tempo } \\ 01 & \text { : Modalitas Intensional } \\ 02 & \text { : Modalitas Epistemik } \\ 03 & \text { : Modalitas Deontik } \\ 04 & \text { : Modalitas Dinamik } \\ 01-d s t & \text { : Data }\end{array}$

3.1 Wujud Keterangan Modalitas dalam berita "Alexis yang Terus Exis" dalam Majalah Tempo edisi 29 Januari-4 Februari 2018

Wujud di sini adalah wujud dari keterangan modalitas. Dalam analisis ini, data dikelompokkan ke dalam keterangan-keterangan modalitas.

a. Keterangan Modalitas Intensional

1) Keinginan

a) Data (MT/01/01): Gubernur DKI Jakarta Anies Baswedan saat itu terlihat antusias memenuhi janji kampanye untuk menutup Alexis. 
Kata antusias di dalam kalimat di atas menjelaskan tentang keinginan Anies Baswedan untuk menutup Alexis. Alexis adalah sebuah hotel dan griya pijat. Hotel ini terletak di Jakarta Utara yang menjadi perbincangan hangat karena oleh Anies Baswedan, hotel ini tidak diperpanjang lagi operasinya. Kata antusias tersebut memiliki kadar keinginan yang secara langsung menjelaskan keinginan akan sesuatu. Hal ini menunjukkan bahwa penulis berita "Alexis yang Terus Exis" dalam Majalah Tempo edisi 29 Januari-4 Februari 2018, menggunakan kata antusias sebagai suatu penilaian positif dari sikap Anies Baswedan yang memiliki keinginan untuk menutup Alexis.

b) Data (MT/01/02): Ihwal LC yang berperan ganda sebagai penjaja jasa seks, Lina pun membantah, "Kami menyediakan LC sesuai dengan fungsi memandu tamu yang ingin berkaraoke."

Kata ingin di dalam kalimat di atas, menjelaskan tentang fasilitas hotel Alexis yang menyediakan tempat karaoke untuk tamu dan LC untuk memandu tamu ketika berkaraoke. Penggunaan kata ingin pada data (MT/01/02) sendiri memiliki kadar "keinginan" yang secara langsung menjelaskan keinginan akan sesuatu. Hal ini menunjukkan bahwa penulis berita "Alexis yang Terus Exis" dalam Majalah Tempo edisi 29 Januari-4 Februari 2018, menggunakan kata ingin sebagai suatu penilaian positif karena kata ini mengandung makna boleh jadi atau tidak dan tidak bersifat memaksa.

Seorang wanita yang bernama Lina Novita Sari dari Legal and Corporate Affairs Grup Alexis menjelaskan bahwa LC yang terdapat di dalam hotel Alexis bukanlah pekerja seks. Ia menjelaskan bahwa LC di hotel tersebut hanya sebagai pemandu tamu yang ingin berkaraoke atau yang lainnya. Sementara itu, salah satu tamu lelaki yang mengunjungi hotel tersebut mengatakan bahwa ia masuk ke dalam ruangan bersama LC tersebut dan melakukan perbuatan asusila.

2) Maksud

a) Data (MT/01/03): Wakil Gubernur DKI Jakarta Sandiaga Uno berjanji menindak tempat hiburan malam yang mengedarkan narkotik. "Jika ditemukan pelanggaran, tentu (ditutup). Kami selalu tegas, untuk itu tidak ada negosiasi," katanya Jumat pekan lalu.

Kata berjanji di dalam kalimat di atas menjelaskan tentang niat yang ingin dilakukan oleh Wakil Gubernur DKI Jakarta Sandiaga Uno. Penggunaan kata berjanji pada data (MT/01/03) sendiri memiliki kadar "maksud" yang secara langsung menjelaskan perjanjian antara dirinya dengan pembaca berita untuk melakukan pemeriksaan pada tempattempat hiburan malam yang mengedarkan narkoba. Hal ini menunjukkan sikap penulis berita "Alexis yang Terus Exis" dalam Majalah Tempo edisi 29 Januari-4 Februari 2018 menggunakan kata "berjanji" sebagai suatu penilaian positif dari sikap Wakil Gubernur DKI Jakarta Sandiaga Uno atas niatannya untuk menghentikan pengedaran narkoba di berbagai tempat hiburan malam.

Tempat hiburan malam merupakan sarana strategis bagi para pengedar narkoba untuk beraksi. Para pengedar dapat dengan mudah 
meracuni para tamu dengan narkoba karena konteks situasi yang mendukung. Demi pemberantasan narkoba di Indonesia, pemerintah selalu melakukan penertiban di setiap tempat yang terindikasi sebagai pemakaian narkoba. Oleh sebab itu, salah satu cara dari berbagai macam cara yang ditempuh oleh Wakil Gubernur DKI Jakarta Sandiaga Uno adalah dengan menutup tempat hiburan malam.

\section{b. Keterangan Modalitas Epistemik}

1) Keharusan

a) Data (MT/02/04): Erick Halauwet, ketua asosiasi itu., mengatakan seharusnya semua tempat hiburan tak membiarkan praktik prostitusi dan peredaran narkotik. "Kalau ada transaksi, silakan tindak tegas," ucap Erick.

Kata seharusnya di dalam kalimat di atas menjelaskan tentang suatu tindakan yang harus dilakukan, yaitu mencegah praktik prostitusi dan peredaran narkotik. Penggunaan kata seharusnya pada data (MT/02/04) sendiri memiliki kadar "keharusan" yang secara langsung menjelaskan tindakan yang harus dilakukan untuk mencegah praktik prostitusi dan peredaran narkotik. Hal ini menunjukkan sikap penulis berita "Alexis yang Terus Exis" dalam Majalah Tempo edisi 29 Januari-4 Februari 2018 menggunakan kata "seharusnya" sebagai suatu penilaian positif dari pernyataan Erick Halauwet sebagai ketua asosiasi karena mendukung pencegahan praktik prostitusi dan peredaran narkotik.

Erick Halauwet adalah ketua Asosiasi Pengusaha Hiburan Jakarta. Dengan adanya tindakan tegas yang dinyatakan langsung oleh ketua asosiasi tersebut diharapkan dapat melancarkan tindakan pencegahan praktik prostitusi dan peredaran narkoba pada tempat-tempat hiburan malam. Selain itu, ia bersikap positif dan tegas apabila ada yang melakukan praktik tersebut.

2) Kepastian

a) Data (MT/02/05): Ihwal peredaran narkotik di tempat hiburan malam, Kepala BNN Budi Waseso meyakini di hampir semua tempat prostitusi terjadi peredaran narkotik.

Kata meyakini di dalam kalimat di atas menjelaskan tentang suatu keyakinan Kepala BNN Budi Waseso terhadap peredaran narkotik di semua tempat prostitusi. Penggunaan kata meyakini pada data (MT/02/05) memiliki kadar "kepastian" yang secara langsung menjelaskan pernyataan yang pasti terhadap peredaran narkotik pada semua tempat prostitusi. Hal ini menunjukkan sikap penulis berita "Alexis yang Terus Exis" dalam Majalah Tempo edisi 29 Januari-4 Februari 2018 menggunakan kata "meyakini" sebagai suatu penilaian positif dari pernyataan Kepala BNN Budi Waseso karena pernyataan tersebut berisi penolakan terhadap peredaran narkotik di tempat hiburan malam. Penulis juga mendukung pernyataan tersebut agar tempat hiburan malam segera ditutup karena terindikasi sebagai tempat peredaran narkotik.

3) Keteramalan

a) Data (MT/02/06): Adapun Lina Novita mengatakan Emporium tak lagi satu grup dengan perusahaannya. "Sepertinya sudah berganti pemilik," ujar Lina, yang 
menyatakan tak tahu pasti siapa pemilik baru Emporium.

Kata sepertinya di dalam kalimat di atas menjelaskan bahwa Lina Novita tidak tahu pasti atas kepemilikan Emporium saat ini. Penggunaan kata sepertinya pada data (MT/02/06) memiliki kadar "keteramalan" yang secara langsung menjelaskan pernyataan ketidakpastian terhadap sesuatu atau pernyataan yang ragu-ragu. Hal ini menunjukkan sikap penulis berita "Alexis yang Terus Exis" dalam Majalah Tempo edisi 29 Januari-4 Februari 2018 menggunakan kata "sepertinya" sebagai suatu penilaian negatif dari pernyataan Lina Novita. Penilaian negatif oleh penulis didasarkan pada adanya indikasi menutupi siapa pemilik Emporium yang merupakan keterangan yang digunakan sebagai bukti.

Lina Novita adalah seorang yang diwawancarai oleh Majalah Tempo karena tidak adanya respon dari pengelola Emporium. Emporium adalah sebuah hotel di Jakarta yang menyajikan striptease tanpa jeda di lantai tiga. Berbeda dengan Hotel Alexis, tari telanjang di hotel ini tak digelar di ruang khusus, tetapi di depan pengunjung. Salah satu tamu yang datang ke Hotel Empirium menyatakan bahwa penari erotis itu bisa diajak berhubungan intim. Oleh sebab itu, Lina Novita menyatakan sikap ketidakpastiaannya terhadap kepemilikan Hotel Emporium agar masalah itu tidak ditanyakan secara lebih mendalam kepada pemiliknya.

4) Kemungkinan

a) Data (MT/02/07):

Kepala Pusat Penerangan TNI Mayor Jenderal Sabrar Fadhilah mengatakan tak mengetahui kemungkinan ada tentara yang terlibat dalam bisnis esek-esek. "Mendatangi tempat hiburan malam saja sudah dilarang, apalagi mengamankan," tuturnya.

Kata kemungkinan pada kalimat di atas menjelaskan bahwa Kepala Pusat Penerangan TNI Mayor Jenderal Sabrar Fadhilah tidak mengetahui secara pasti akan indikasi tentara yang terlibat dalam bisnis esek-esek di tempat hiburan malam. Penggunaan kata kemungkinan pada data (MT/02/07) memiliki kadar "kemungkinan" yang secara langsung menjelaskan sesuatu yang belum pasti karena belum adanya bukti. Hal ini menunjukkan sikap penulis berita "Alexis yang Terus Exis" dalam Majalah Tempo edisi 29 Januari-4 Februari 2018 menggunakan kata "kemungkinan" sebagai suatu penilaian negatif terhadap tempattempat hiburan malam. Pernyataan yang diberikan oleh Kepala Pusat Penerangan TNI Mayor Jenderal Sabrar Fadhilah terhadap bisnis esekesek yang dilakukan oleh tentara tidak terlalu menarik baginya karena adanya tambahan pernyataan bahwa tidak diperbolehkannya tentara mengamankan tempat hiburan malam.

\section{c. Keterangan Modalitas Dinamik}

1) Kemampuan

a) Data (MT/03/08): Seorang pelanggan klub mengatakan penari erotis itu bisa diajak berhubungan intim dengan tarif Rp 2 juta per jam.

Kata bisa pada kalimat di atas menjelaskan bahwa salah satu tamu pelanggan club yang mengunjungi Hotel Emporium menyatakan bahwa penari erotis di hotel tersebut bisa diajak berhubungan intim sesuai dengan tarif. Penggunaan kata bisa 
pada data (MT/03/08) memiliki kadar "kemampuan" yang secara langsung menjelaskan sesuatu secara pasti mampu untuk melakukan sesuatu. Hal ini menunjukkan sikap penulis berita "Alexis yang Terus Exis" dalam Majalah Tempo edisi 29 Januari-4 Februari 2018 menggunakan kata "bisa" sebagai suatu penilaian positif terhadap pernyataan tamu tersebut karena tamu tersebut mau melakukan hubungan intim di Hotel Emporium. Selain itu, tamu tersebut berani untuk terbuka memberikan bukti-bukti bahwa Hotel Emporium bukan hanya sebagai tempat hiburan, tetapi juga sebagai tempat prostitusi. Hal tersebut menjadikan penguat bahwa tempat hiburan dapat pula dijadikan sebagai tempat prostitusi.

\section{d. Keterangan Modalitas Deontik}

1) Izin

a) Data (MT/04/09): Buwas menilai tidak diperpanjangnya izin satu-dua tempat hiburan malam tak berpengaruh terhadap peredaran narkotik. "Masih ada ratusan, mungkin ribuan, tempat hiburan lain yang juga menyediakan narkoba," ujar mantan Kepala Badan Reserse Kriminal Markas Besar Kepolisian RI ini.

Kata tidak diperpanjangnya izin pada kalimat di atas menjelaskan bahwa telah dilakukannya penutupan pada tempat hiburan malam tidak berpengaruh terhadap peredaran narkotik. Penggunaan kata tidak diperpanjangnya izin pada data (MT/04/09) memiliki kadar atas sesuatu yang terkait dengan "keizinan" yang secara langsung menjelaskan tindak penolakan. Hal ini menunjukkan bahwa sikap penulis berita "Alexis yang Terus Exis" dalam Majalah Tempo edisi 29 Januari-4 Februari 2018 menggunakan kata "tidak diperpanjangnya izin" sebagai suatu penilaian negatif terhadap tempat hiburan malam yang diindikasi sebagai tempat peredaran narkoba. Selain itu, dengan ditutupnya tempat hiburan malam, tidak menutup kemungkinan peredaran narkotik akan berhenti.

\section{KESIMPULAN}

Penelitian ini menggunakan teori keterangan modalitas oleh Alwi dalam mengklasifikasikan wujud keterangan modalitas berita "Alexis yang Terus Exis" dalam Majalah Tempo edisi 29 Januari-4 Februari 2018 melalui kalimat-kalimat dalam berita tersebut. Dari hasil analisis dapat disimpulkan bahwa penelitian tentang keterangan modalitas berita "Alexis yang Terus Exis" dalam Majalah Tempo edisi 29 Januari-4 Februari ditemukan wujud katerangan modalitas intensional, epistemis, dinamik, dan deontik. Unsur kata yang ditemukan adalah ingin, antusias, berjanji, seharusnya, meyakini, membenarkan, menurut, sepertinya, kemungkinan, bisa, dan izin. Selain itu, perspektif penulis berita Majalah Tempo dalam menanggapi wujud keterangan modalitas modalitas tersebut adalah perspektif positif dan negatif.

Penelitian ini dapat memberikan manfaat pada mahasiswa khususnya dalam mata kuliah Sintaksis dan Semantik dalam mengalisis pola dan makna dalam sebuah kalimat. Selain itu, dalam pembelajaran di sekolah, dapat memberikan pemahawan dan wawasan bagi guru untuk lebih komprehensif dalam memberikan mata pelajaran terkait dengan struktur dalam kalimat, 
khususnya fungsi keterangan dalam kalimat.

\section{DAFTAR PUSTAKA}

Achmad, HP. \& Abdullah, Alek. (2002). Linguistik Umum. Jakarta: Erlangga.

Alwi, Hasan. (1990). Modalitas dalam Bahasa Indonesia. Yogyakarta: Kanisius.

Badara, Aris. (2012). Analisis Wacana (Teori, Metode, dan Penerapannya Pada Wacana Media). Jakarta: Kencana.

Barus, Sedia Willing. (2010). Jurnalistik (Petunjuk Teknik Menulis Berita). Jakarta: Erlangga.

Chaer, Abdul. (1994). Linguistik Umum. Jakarta: Rineka Cipta.

Dewabrata, A.M. (2004). Kalimat Jurnalistik (Panduan Mencermati Penulisan Berita). Jakarta: PT Kompas Media Nusantara.

Junaiyah, H.M. \& Arifin, Zaenal. E. (2010). Keutuhan Wacana. Jakarta: Grasindo.

Kushartanti, dkk. (2007). Pesona Bahasa (Langkah Awal Memahami Linguistik). Jakarta: PT Gramedia Pustaka Utama.

Markhamah. (2009). Ragam dan Analisis Kalimat Bahasa Indonesia. Surakarta: Muhammadiyah University Press.

Parera, J.D. (2009). Dasar-Dasar Analisis Sintaksis. Jakarta: Erlangga.

Rizki, J.W.S. (2016). Kepemilikan Media dan Ideologi Pemberitaan. Yogyakarta: Deepublish.

Widjono, H.S. (2007). Bahasa Indonesia (Mata Kuliah Pengembangan Kepribadian di Perguruan Tinggi). Jakarta: PT Grasindo.
Zen, Fathurin. (2004). NU Politik (Analisis Wacana Media). Yogyakarta: LKiS. 